\title{
Interview
}

\section{On the Freedom of Speech and Expression: Interview with Noam Chomsky}

\author{
Noam Chomsky, Beatrice Popescu*a \\ [a] EJOP Founding Editor; University of Bucharest, Bucharest, Romania.
}

Europe's Journal of Psychology, 2013, Vol. 9(2), 214-219, doi:10.5964/ejop.v9i2.574

Received: 2013-01-18. Accepted: 2013-01-18. Published: 2013-05-31.

${ }^{*}$ Corresponding author at: 4-6 Bucur Street, Bucharest, Romania, 040292. E-mail: beatrice.popescu@ejop.org

(i) This is an open access article distributed under the terms of the Creative Commons Attribution License

(c) (i) (http://creativecommons.org/licenses/by/3.0), which permits unrestricted use, distribution, and reproduction in any medium, provided the original work is properly cited.

Beatrice Popescu: Professor Chomsky, it is a great honor to talk to you; thank you for your precious time.

It would be almost impossible to reduce all your work to one field or theme, and this is why I will try to touch on a few themes from the whole array of contributions you have made to science and human knowledge and spirit. You epitomized for years the freedom of expression for academics, media and the general public. How do you feel having such a distinctive tone in voicing the unspoken words of billions of people? Does it come as a great responsibility or as an exceptional emotionally charged challenge?

Noam Chomsky: To the extent that the tone is "distinctive," that is a failure of the intellectual community, those who enjoy privilege and have the opportunity to defend such elementary values as freedom of expression, and much else, if they choose.

Beatrice Popescu: As we all know, you are constantly deluged with interview requests from the media, especially on the latest international political issues, so dramatic that cannot suffer any delay. What convinced you to offer us an interview?

Noam Chomsky: I do as much as I can, a fraction of what I would like. This seemed to me an unusual and attractive opportunity to engage in discussion with people with common interests whom I would very much like to meet in person, if I were able to arrange a visit to a part of the world where I have almost never been.

Beatrice Popescu: We would be happy to invite you to Bucharest. Starting with psycholinguistics, I have noticed that a huge majority of academics never change their mind about anything, locking into a rigid position earlier in their careers, which they defend to the end of time. You, Professor, in contrast, have never stopped critiquing your own theories with the same energy with which you have criticized those of others (Skinner or Shannon). For almost half a century, your search for linguistic truth has been uncompromising. Looking at your prodigious career in psycholinguistics and especially at the newest perspective on "generative grammar", the Minimalist program, are there still any fundamental questions you did not consider in your research, are there any topics left out from the vigilant eye of the researcher? 
Noam Chomsky: Revision of one's views is quite normal in a field that is alive and dynamic. Are there fundamental questions that remain only a gleam in the eye? Far too many to list: the more we learn, the more we discover that we do not understand. Take just the most obvious of these questions. Fifty years ago I quoted Wilhelm von Humboldt's characterization of language as "infinite use of finite means." A lot has been learned about the finite means, though there is still a great deal that is barely understood about these very difficult questions. But there has been very little progress in studying the use of these means - the "creative aspect of language use" that was a core feature of Cartesian philosophy, and has remained largely a mystery ever since.

Beatrice Popescu: Steven Pinker acknowledged you as a tremendous inspiration for his own research into the developmental psychology of children, especially in relation to language instinct, which is believed to be innate. Could you please tell us who was your early inspiration for your own research, if this was the case? Also, do you still believe that evolutionary psychology is not able to fully explain the human language instinct? Should we worry that the "innate" theory strengthens supporters of extreme genetic determinism, leaving out completely the standard social science model?

Noam Chomsky: I was, of course, greatly influenced by many people who I either knew personally or whose work I read, including some in the fields in which I have worked. But my main "inspiration" in my professional work has been the challenging problems that arise at once as soon as we allow ourselves to be puzzled by what seem to be obvious and simple facts - much as modern science really began when Galileo and others were dissatisfied with the answer that had been accepted for millennia to simple question: For example, why do rocks fall while steam rises: They seek their natural place. I wouldn't say that evolutionary psychology "is not able to fully explain the human language instinct." Rather, it has virtually nothing to say about it. There is no "innate" theory. Everyone rational must recognize that there is some genetic element that distinguishes humans from cats, apes, birds, etc., with regard to language learning. The question is: What is it? The answer is an "innate" theory. It has been understood for a long time, of course, that innate properties typically must be triggered and shaped by experience, so there are invariably complex interactions. There is no reason to be worried about the results of such investigations, or to believe that what might be discovered would support conclusions with harmful human consequences. Quite the contrary. We should hope that such discoveries might someday provide understanding of the nature of human freedom and the ways to enhance it, carrying for-

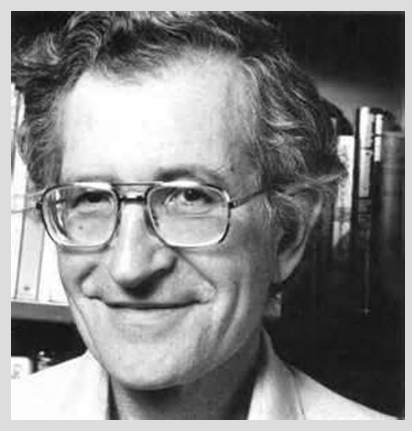

Professor Noam Chomsky was born in Philadelphia and educated at the University of Pennsylvania, where he received his PhD. In 1955 he was appointed to the faculty of the Massachusetts Institute of Technology (MIT), where he has served as professor of foreign languages and linguistics.

Chomsky is credited with the creation of the theory of generative grammar, often considered to be the most significant contribution to the field of theoretical linguistics in the 20th century. Through his review of B. F. Skinner's Verbal Behavior he helped spark the cognitive revolution in psychology, in which he challenged the behaviorist approach to the study of mind and language dominant in the 1950s. His naturalistic approach to the study of language has affected the philosophy of language and mind. He is also credited with the establishment of the so-called Chomsky hierarchy, a classification of formal languages in terms of their generative power. Chomsky taught courses and lectured at many universities throughout the world, including Oxford University.

Besides his work in the field of psycholinguistics, Chomsky is also well-known as a leftist activist and social critic. He was an outspoken opponent of the Vietnam War and has remained critical of media coverage of politics. Chomsky is an incisive critic of the ideological role of the mainstream corporate mass media, which, he maintains, "manufactures consent" toward the desirability of capitalism and the political powers supportive of it. 
ward leading concerns of the Enlightenment and since - and incidentally, perhaps approaching some understanding of Humboldt's observation.

Beatrice Popescu: Since you evoked one of the founders of classical liberalism, Wilhelm von Humboldt, I would also like to bring up Adam Smith's name. His early view on corporations was that they were the principal architects of policy which consolidate state power and use it for their own interest. What do you think Smith would say today about neocorporatism, if he was alive?

Noam Chomsky: To be a bit more precise, Smith did not refer to corporations, which were nothing like what they are today. Rather, he referred to "merchants and manufacturers," those who had the dominant role in the economy and society in his day, who he elsewhere called "the masters of the universe." That is the role that is now played by megacorporations, increasingly financial in the West. If Smith were alive today I presume he would be aghast, and would say the same thing about today's far more powerful masters of the universe and their "grievous" impact on others, including the citizens of the states on which they crucially rely.

Beatrice Popescu: We were all extremely impressed seeing you on the Occupy event scene boldly taking a stand when state authorities have tried to minimize the impact of the movement. We have also seen that Alain Badiou has chosen to back the event. Is Occupy more of a philosophical paradigmatic change or a revolutionary movement as a reaction to the status quo?

Noam Chomsky: I don't think either term is accurate. The Occupy movement is one of many reactions to the neoliberal assault on the populations over much of the world. The effects have generally been harmful, sometimes severely so, and they have elicited reactions. One of the most important was in Latin America, which had been one of the prize pupils of the doctrine, lauded by the designers for adhering so dutifully to the precepts of the Washington Consensus. It had also, not surprisingly, suffered even more than most. About ten years ago Latin Americans reacted in a manner of true historical significance. The policies were rejected, in whole or in large part. For the first time in 500 years, Latin America moved significantly to free itself from colonial domination, to integrate, and to face some of its incredible internal problems. By now the U.S. has been virtually excluded from South America, and its dominance elsewhere has also declined. The Arab Spring is another step in the same direction: One factor in the uprising was protest against the neoliberal programs, which, as almost everywhere, harmed the large majority of the population while providing enormous wealth to a tiny elite. The Occupy movement in the U.S. was a similar reaction. It began with establishment of a tent city in Zuccotti Park New York, near the Wall Street financial district, the main perpetrators of the current financial crisis, and more generally of the neoliberal programs, in close collusion with the government, which has been increasingly dominated by financial institutions. It quickly spread all over the country, and far beyond. I have given talks to Occupy activists from England to Australia. It has also linked up with similar uprisings in Europe: the Indignados in Spain and others.

Beatrice Popescu: The 99\% movie directed by Celik Kalayar, the story of Anne Page, which you endorsed, moved me to tears."The Occupy Wall Street movement no longer occupies Wall Street, but the issue of class conflict has captured a growing share of the national consciousness. A new Pew Research Center survey of 2,048 adults finds that about two-thirds of the public (66\%) believes there are 'very strong' or 'strong' conflicts between the rich and the poor - an increase of 19 percentage points since 2009." Do you think rich and poor will reconcile their positions in the future? $99 \%$ could become an $80 \%$ at some point? 
Noam Chomsky: One of the achievements of the movement was to bring the issues of extreme inequality and class conflict to the agenda of public discussion, concern, and activism. That is what accounts for the sharp increases in poll results to which you refer. Just how such movements will develop, one can never predict, but they have already had quite a considerable impact, and they might carry far beyond.

Beatrice Popescu: British democratic socialist George Orwell was a strong influence in your youth; more than this, his work almost convinced you that an anarcho-syndicalist society was possible. Having dealt for so many years with U.S. politics and trying hard to convince people to understand the true depth of U.S. leaders' cruel treatment of the world's nonpeople, don't you feel sometimes like you share a common destiny with 1984's protagonist, Winston Smith? Can we draw parallels between the society we live in and the dystopian world imagined by Orwell in 1944 ?

Noam Chomsky: I did read Orwell as a teenager, and was impressed mostly by his early work, like Homage to Catalonia. But it did not really influence my views much. I was committed to an anarcho-syndicalist vision well before I read his writings about it - and he himself, though quite sympathetic to the revolutionary workers in Catalonia and what they were doing, did not really approve of the anarcho-syndicalist revolution in Spain, which he also did not know much about, as he conceded. He was a member of the POUM militia, a Trotskyite offshoot. I don't frankly find much value in the analogies to his book 1984, not one of my favorites.

Beatrice Popescu: In many of your conferences held in university campuses, you advocate for the independence of academia and for the need to decorporatize the higher education institutions. Can you please explain to our readers, in a few words, why is it so crucial that undergraduate and graduate schools need not rely heavily on money obtained from corporations?

Noam Chomsky: Corporate funding comes with strings attached. Corporations are not dedicated to the general welfare, of course. And those constraints interfere with academic freedom, virtually by definition. Perhaps there is no alternative, but if so, vigilance and resistance are required.

Beatrice Popescu: In a discussion on education and democracy at a Dutch university (2011), you were quoting from the report on the "crisis of democracy" by the Trilateral Commission, basically liberal internationalists from the U.S., Europe, and Japan. The concern of the book is that there is too much democracy and that the "institutions responsible for indoctrination of the young" (schools, churches, universities) have failed. Could you please elaborate a little for our readers?

Noam Chomsky: They were charging that there is "excessive democracy" and were calling for "moderation in democracy". They criticized the schools, universities, churches for allowing too much freedom and independence, instead of attending to their responsibility for "indoctrination of the young" in passivity and obedience. Exactly what we should be opposing, in my opinion.

Beatrice Popescu: I am familiar with your views on liberation theology considered as a preferential option of the poor and it seems that your primary argument is not against religion or the belief in a higher power, but rather how this intrinsic phenomenon is distorted and manipulated to control and subordinate the masses, considering that man is obedient by nature. The power elite, here or elsewhere, acknowledges it and also exploits it. Is there a solution for creating a world where humanist values deserve a better place? 
Noam Chomsky: The core doctrine of liberation theology was "the preferential option of the poor," as in the Gospels. I have no general argument against religion. It is not for me, but if others choose to accept beliefs in a divine spirit, the Abrahamic deity, or some other form of extra-natural entity, that is their right, as long as it does not infringe on the rights of others. On creating a world dedicated to humanist values, there are innumerable ways to proceed.

Beatrice Popescu: Talking about the poor, we witness a huge increase in unemployment in Western European countries, which translates as a social component in many attacks against immigrant communities. What is even more worrying than before, there are cases of unemployment and also homelessness amongst educated people, even postgraduates. Do you have any comments on this?

Noam Chomsky: There are many causes, among them the programs of austerity during recession, which have, predictably, intensified the crises of stagnation of Western European countries.

Beatrice Popescu: One of your favorite themes is propaganda. In the preface of your book "Necessary lllusions, Thought Control in Democratic Societies", you say that your feeling is that "citizens of the democratic societies should undertake a course of intellectual self-defense to protect themselves from manipulation and control" in order to create a more meaningful democracy. Unlike totalitarian regimes, in democracy the "necessary illusions" may not be imposed by force and this is why they must be inculcated in people's minds by more subtle means. Who could teach us to become literate in self-defense strategies? Should we expect that some of us have innate complex cognitive processes (or develop structures later in life) that protect us from being manipulated?

Noam Chomsky: My feeling is that all normal people share the capacity to recognize and resist manipulation, though like other capacities, they have to be stimulated and exercised to become effective.

Beatrice Popescu: You prefer to call yourself a libertarian socialist opposed to just libertarian. You also dislike Ayn Rand, whom you consider one of the most evil figures of modern intellectual history. Could Rand's objectivism be the philosophical foundation for the financial capitalism in its hideous shape and form we witness today?

Noam Chomsky: Rand's "libertarianism", apart from being morally grotesque, is basically a prescription for centralized control by unaccountable private power. It has no intrinsic relation to financial capitalism, though advocates of such social forms might (and sometimes do) appeal to Randian conceptions to justify their practices.

Beatrice Popescu: At the end of our talk, let's get back to psychology, which is still as we are speaking, a young science struggling to hold its status in front of other well-established scientific domains. What do you think psychology needs more, except for structure, in order to become a more reputable science such as philosophy, logic, hermeneutics, metaphysics and medical science? Does it need a multilevel type of reconstruction, from research methodology to the means of intervention?

Noam Chomsky: Psychology covers a very broad range. Different branches have different needs. I do not see the domains you mention as obstacles.

Beatrice Popescu: In this era full of controversy in almost every major area of our lives, what do you think could make us less vulnerable to current changing trends? I personally think that family values, passion in our work and a healthy form of activism could make our lives full of meaning and scope. Do you share a different view? Professor Chomsky, do you regard the future with optimism? 
Noam Chomsky: Those seem to me good suggestions. Whether we regard the future with optimism or not is a personal matter, of no general import as far as I can see. Whatever our subjective and highly uncertain judgments might be about human prospects, we should be pursuing essentially the same course.

Beatrice Popescu: Professor Chomsky, thank you again for your time. 